\title{
Synthesis, Characterization, In vitro Antiproliferative and Cytotoxic Effect of Ruthenium(II)-Bipyridine-Benzoylpicolinic Acid Complex on SK-MEL-28 and Normal L6 Cell Lines
}

\author{
Santhiya Sivaraman ${ }^{1}$ and Sheeba Daniel, ${ }^{2, *}$ \\ ${ }^{I}$ Department of Chemistry, Good Shepherd College of Engineering and Technology, Kaliyal, \\ Tamil Nadu, India \\ ${ }^{2}$ Department of Chemistry, Holy Cross College (Autonomous), Nagercoil, Tamil Nadu, India
}

('Corresponding author's e-mail: sheebadaniel@holycrossngl.edu.in)

Received: 10 March 2021, Revised: 8 June 2021, Accepted: 18 June 2021

\begin{abstract}
The most seriously spread malignant tumor of melanocytes throughout the body is a melanoma type of skin cancer. SK-MEL-28 cell line is one of a series of melanoma cell lines. The objective of the present investigation is to study the anticancer activity and cytotoxicity of novel $\left[\mathrm{Ru}(\mathrm{bpy})_{2}(\mathrm{bzpic})_{2}\right]^{2+}\left(\mathrm{bpy}=2,2^{\prime}-\right.$ bipyridine and bzpic = 3-Benzoylpicolinic acid) complex on SK-MEL-28 and normal L6 cell lines using MTT assay method. The morphology of the cancerous SK-MEL-28 cell line at various concentrations of the $\left[\mathrm{Ru}(\mathrm{bpy})_{2}(\text { bzpic })_{2}\right]^{2+}$ complex is assessed by 2 -fold dilution method, and the in vitro antiproliferative effect of the complex on the cancerous SK-MEL-28 cell line is analyzed by direct microscopic observation method. The percentage viability of the complex on cancerous SK-MEL-28 cell line at various concentrations is determined. The $\mathrm{IC}_{\mathbf{5 0}}$ value of the complex against the SK-MEL-28 cell is found to be $39.109 \mu \mathrm{g} / \mathrm{mL}$ which shows good antiproliferative effect. The $\mathrm{IC}_{\mathbf{5 0}}$ value of the complex against normal L6 cell line is found to be $55.315 \mu \mathrm{g} / \mathrm{mL}$. The results revealed that the percentage of growth inhibition of the cell is based on dose-dependent manner and the formation of formazan crystal indicates this. The fluorescent microscopy observation clearly determines that the synthesized $\left[\mathrm{Ru}(\mathrm{bpy})_{2}(\mathrm{bzpic})_{2}\right]^{2+}$ complex shows late apoptosis on SK-MEL-28 cell line and early apoptosis on L6 cell line. Hence, it is evident that the synthesized complex exhibits good in vitro antiproliferative effect with lower cytotoxicity.
\end{abstract}

Keywords: $\left[\mathrm{Ru}(\mathrm{bpy})_{2}(\text { bzpic })_{2}\right]^{2+}$ complex, SK-MEL-28 and L6 cell lines, MTT assay, Antiproliferative effect, Fluorescence microscopy, Anti-skin cancer activity

\section{Introduction}

Skin cancer is the most common form of human cancer, and one of the types of skin cancer is melanoma. The primary cause of premature death from cancer is melanoma. Early detection of the primary melanoma developed is associated with improved survival. The changes in the skin such as soreness, unusual growth or a change in an existing mole, skin appearance, and new growth lead to basal cell and squamous cell carcinoma. Melanocytes produce the dark pigment melanin, which are normally present in the skin [1]. Superficial spreading of melanomas that lack melanin pigment can be treated by in vivo, and in vitro methods with an attractive therapeutic target, chemotherapy agents, make an important contribution to melanoma in the future [2]. Apoptosis is a self-destruction complex and a biochemical process of cells in a multicellular organism. A programmed cell death maintains tissue homeostasis, fetal development, and aging [3]. During apoptosis, the surrounding cells and cellular macromolecules are digested into smaller fragments. In a controlled fashion, the cells are collapsed into smaller intact fragments and are removed by phagocytosis without damaging [4].

Due to the rapid increase in cancer cases, researchers make many efforts to produce effective chemotherapeutic and diagnostic agents to inhibit and detect cancer cells. Cisplatin has been established as an antineoplastic agent for the treatment of various cancer cells since the 1960s. Later it was identified that cisplatin has significant side effects and some limitations. Consequently, these limitations induce the researchers to develop novel therapeutic and diagnostic agents for cancer therapy, drug delivery, biosensing, and imaging [5,6]. 
Transition metal complexes have been extensively studied due to their potential applications in biological processes, and it has been developed as antitumor agents. Among the different metal complexes, ruthenium complexes are stable and easily accumulate in cancer tissues [7]. The most promising biological features of ruthenium complexes include bio-distribution and are less toxic than cisplatin, which is active against tumors [8]. Due to its photophysical properties, charge, solubility and lipophilicity, $\mathrm{Ru}(\mathrm{II})$-polypyridyl complexes acts as potential cellular imaging for antitumor drugs, cellular targeting and therapeutic agents. Ru(II)-polypyridyl complexes non-covalently interact with biomolecules lends itself to design new therapeutic agents. Upon light activation $\mathrm{Ru}(\mathrm{II})$-polypyridyl complexes may elicit their biological activity. The size of the polypyridyl ligand coordinated to the Ru(II) centre incorporates more extended aromatic ligands tends to be of considerable importance and show greater biological activity. The overall function of the $\mathrm{Ru}$ (II) complexes are determined by the structural nature of the polypyridyl units present in the metal complex [9-11]. The aim of discovering anti-cancer therapeutics is to arrest cancer cells' proliferation and elicit cell death by damaging cells. Thus ruthenium complexes have shown great potential, generating interests in the subject of extensive drug discovery efforts and acting as novel anticancer drugs by overcoming the limitations [12-14].

Picolinic acid, an isomer of nicotinic acid, is an $\alpha-\mathrm{N}$ heterocyclic carboxylic acids consist of 6membered ring structure containing a carboxyl group at the second position of the pyridine ring. Picolinic acid has been detected in various biological mediums that include human milk, pancreatic juice, cell culture supernatants, blood serum, cerebrospinal fluid, and intestinal homogenates [15]. Picolinic acidmetal complexes are now widely introduced as bioactive metals into biological systems [16]. The picolinic acid is a strong chelating agent. The chelation properties of picolinic acid capitalize the in vitro studies, suggesting that it may enhance macrophage effector functions [17]. Pyridine rings in picolinic acid are recognized as effective bidentate $\mathrm{N}-\mathrm{O}$ donor forming a 5-membered chelates with simple metal ions. In general, it stabilizes the ruthenium(II) acceptor metal centre and are expected to have more stabilizing effect and coordinate towards $\mathrm{Ru}(\mathrm{II})$ and $\mathrm{Ru}(\mathrm{III})$ complexes [18]. The basic pyridine nitrogen possesses $\pi$-acceptor properties, helps to solubilize the metal that are involved in $\pi$ - $\pi$ stacking effects with purine and pyrimidine bases. It is considered as a non-active ingredient through the formation of chelate complex [19].

Investigations on the biological activities of $\mathrm{Ru}(\mathrm{II})$-polypyridyl complexes have been made so far, and the present study concentrates on the in vitro antiproliferative and cytotoxic effects of $\left[\mathrm{Ru}(\text { bpy })_{2}(\text { bzpic })_{2}\right]^{2+}$ (bpy $=2,2^{\prime}$-bipyridine and bzpic $=3$-benzoylpicolinic acid) complex on SK-MEL-28 and normal L6 cell lines using MTT assay method. The morphology of the cancerous SK-MEL-28 and normal L6 cell lines at various concentrations of $\left[\mathrm{Ru}(\mathrm{bpy})_{2}(\mathrm{bzpic})_{2}\right]^{2+}$ complex is carried out by direct and fluorescent microscopic observation methods.

\section{Materials and methods}

\section{Materials}

$\mathrm{RuCl}_{3} \cdot 3 \mathrm{H}_{2} \mathrm{O}$, ligands (bpy and bzpic) and ammonium hexafluorophosphate $\left(\mathrm{NH}_{4} \mathrm{PF}_{6}\right)$ were procured from Sigma-Aldrich. HPLC grade solvents were used for the synthesis of the complex. SK-MEL 28 cell line was procured from the National Centre for Cell Sciences. The in vitro antiproliferative studies on SKMEL-28 and L6 cell lines were carried out in Dulbecco's Modified Eagles Medium (DMEM, Himedia) supplemented with $10 \%$ FBS (Fetal Bovine Serum), L-glutamine, sodium bicarbonate and antibiotic solution containing Penicillin $(100 \mu \mathrm{g} / \mathrm{mL})$, Streptomycin $(100 \mu \mathrm{g} / \mathrm{mL})$ and Amphotericin B $(2.5 \mu \mathrm{g} / \mathrm{mL})$.

\section{Synthesis of precursor $\left[\mathrm{Ru}(\mathrm{bpy})_{2} \mathrm{Cl}_{2}\right] 2 \mathrm{H}_{2} \mathrm{O}$ complex}

$\mathrm{RuCl}_{3} \cdot 3 \mathrm{H}_{2} \mathrm{O}$, bpy and $\mathrm{LiCl}$ were refluxed in DMF for $8 \mathrm{~h}$. The reaction mixture was cooled to room temperature. The mixture was then filtered, yielding a red-violet filtrate and a black crystalline substance. The solid was washed 3 times with water followed by diethyl ether and was subsequently dried by suction. This complex was then recrystallized from ethanol and used as precursor for the synthesis of $\left[\mathrm{Ru}(\mathrm{bpy})_{2}(\text { bzpic })_{2}\right]^{2+}$ complex.

\section{Synthesis of $\left[\mathbf{R u}(\text { bpy })_{2}(\text { bzpic })_{2}\right]^{2+}$ Complex}

$\left[\mathrm{Ru}(\mathrm{bpy})_{2} \mathrm{Cl}_{2}\right](1 \mathrm{mmol})$ and bzpic $(2 \mathrm{mmol})$ were dissolved in $20 \mathrm{~mL}$ of methanol and refluxed for $4 \mathrm{~h}$ under nitrogen atmosphere. The solution was then allowed to cool at room temperature and filtered to remove any insoluble impurities. A saturated solution of $\mathrm{NH}_{4} \mathrm{PF}_{6}$ was then added dropwise into the filtrate until a red precipitate was formed. The product was filtered, washed with cold water, and diethyl ether and further dried in a vacuum desiccator. The complex was purified by column chromatography using 
silica gel as the adsorbent and a mixture of methanol and dichloromethane (2:8 ratio) as an eluent and subsequent evaporation to recover the complex. The absorption maximum $\left(\lambda_{\max }\right)$ of this complex in acetonitrile was $476.5 \mathrm{~nm}$. FTIR (KBr pellet): 3583, 2920, 2852, 1788, 1764, 1653, 1662, 1681, 1585, $1558,1473,1411,1286,1321,1336,1344,1379,1321,947$ and $844 \mathrm{~cm}^{-1} .{ }^{1} \mathrm{H}$ NMR (DMSO-d $\left.6, \delta \mathrm{ppm}\right)$, [bpy: $8.84(1 \mathrm{H}, \mathrm{d}), 8.68(1 \mathrm{H}, \mathrm{d}), 7.64(1 \mathrm{H}, \mathrm{t}), 7.23(1 \mathrm{H}, \mathrm{t})$; bzpic: $9.99(-\mathrm{OH}), 8.86(1 \mathrm{H}, \mathrm{d}), 8.19(2 \mathrm{H}, \mathrm{t})$, $8.23(1 \mathrm{H}, \mathrm{d}), 7.89(1 \mathrm{H}, \mathrm{d}), 7.61(2 \mathrm{H}, \mathrm{t}), 7.64(2 \mathrm{H}, \mathrm{t})] .{ }^{13} \mathrm{C}$ NMR (DMSO d $\left.6, \delta \mathrm{ppm}\right): 151.60(-\mathrm{COOH})$, $137.54,136.26,129.06,127.99,127.53,124.35$ (aryl carbons), 187.57(C=O) Keto group. Elemental analysis: $\mathrm{C}=63.66 \%, \mathrm{H}=3.95 \%, \mathrm{~N}=9.68 \%, \mathrm{O}=11.06 \%$ (experimental) $\mathrm{C}=65.52 \%, \mathrm{H}=4.45 \%, \mathrm{~N}$ $=10.01 \%, \mathrm{O}=11.97 \%$ (calculated). The experimental value was in accordance with the theoretical value. MALDI-TOF-MS (m/z): [Ru(bpy) $\left.)_{2}(\text { bzpic })_{2}\right]\left(\mathrm{PF}_{6}\right)_{2}$ complex m/z is found to be $1157.137\left(\mathrm{M}^{+}\right)$, $1012.345\left(\mathrm{M}^{+}-\mathrm{PF}_{6}^{-}\right)$and $867.994\left(\mathrm{M}^{+}-2 \mathrm{PF}_{6}^{-}\right)$.

\section{Equipment}

The absorption spectrum of synthesized $\left[\mathrm{Ru}(\mathrm{bpy})_{2}(\mathrm{bzpic})_{2}\right]^{2+}$ complex was measured using SHIMADZU UV 1800 double beam spectrophotometer. The FTIR spectral analysis was measured using FTIR SHIMADZU double beam spectrophotometer. The ${ }^{1} \mathrm{H}$ and ${ }^{13} \mathrm{C}$ NMR spectrum was measured using BRUCKER spectrometer. The MALDI-TOF analysis was carried out to determine the $\mathrm{m} / \mathrm{z}$ peak using Bruker Daltonics Flex-PC microflex Analysis. SK-MEL-28 and L6 cell lines were seeded in 96 well plate tissue culture plate and incubated at $37{ }^{\circ} \mathrm{C}$ in a humidified $5 \% \mathrm{CO}_{2}$ incubator (Galaxy® 170 Eppendorf, Germany). The anti-proliferative effect evaluation was carried out using inverted phase contrast tissue culture microscope (LabomedTCM-400 with MICAPS TM HD camera). All the absorbance values measured during MTT Assay were recorded by using microplate reader at a wavelength of $570 \mathrm{~nm}$. Fluorescent microscopic image of the sample was analyzed by Olympus CKX41 with OptikaPro5 camera.

\section{Evaluation of antiproliferative effect by MTT assay method}

Sample solutions of $\left[\mathrm{Ru}(\mathrm{bpy})_{2}(\text { bzpic })_{2}\right]^{2+}$ complex was freshly prepared for evaluation of in vitro antiproliferative effect. The freshly prepared samples in $5 \%$ DMEM, was initially filtered to ensure the sterility [20]. Two-fold dilution of the freshly prepared samples were 5 times serially diluted as $6.5,12.5$, $25,50,100 \mu \mathrm{g}$ in $100 \mu \mathrm{L}$ of $5 \%$ DMEM. The diluted samples were added in triplicates to the respective 96 cell well plates and incubated at $37{ }^{\circ} \mathrm{C}$ in a humidified $5 \% \mathrm{CO}_{2}$ incubator. The 96 well tissue culture plate was observed at an interval of each $24 \mathrm{~h}$, up to $72 \mathrm{~h}$ in an Inverted phase contrast tissue culture microscope and microscopic observation were recorded. Any changes in the morphology of the cells were considered as indicators of anti-proliferative effect. For MTT assay, $15 \mathrm{mg}$ of MTT was reconstituted in 3 $\mathrm{mL}$ Phosphate-buffered saline (PBS) and sterilized by filter sterilization. After $24 \mathrm{~h}$ of incubation period the MTT solution was added to all test and control wells, the plate was gently shaken well, then incubated at $37{ }^{\circ} \mathrm{C}$ in a humidified $5 \% \mathrm{CO}_{2}$ for $4 \mathrm{~h}$. The supernatant solution was removed, $100 \mu \mathrm{L}$ of DMSO was added to solubilize the formazan crystals, and the absorbance values were measured at $570 \mathrm{~nm}$. The $\mathrm{IC}_{50}$ value of the complex on SK-MEL-28 and normal L6 cell lines was determined from the percentage cellular viability.

$$
\% \text { of cellular viability }=\frac{\text { Mean OD samples }}{\text { Mean OD of control group }} \times 100
$$

\section{Determination of apoptosis by double staining method}

The apoptosis was determined by double staining method after treating the test sample at $\mathrm{IC}_{50}$ concentration. The test sample along with the cells at $\mathrm{IC}_{50}$ concentration was incubated in a $\mathrm{CO}_{2}$ incubator for $24 \mathrm{~h}$ and the cells were washed by cold PBS to maintain the $\mathrm{pH}$. The cells were stained with a mixture of acridine orange $(\mathrm{AO}, 100 \mu \mathrm{g} / \mathrm{mL})$ and ethidium bromide $(\mathrm{EB}, 100 \mu \mathrm{g} / \mathrm{mL})$ at room temperature for 10 min. The stained cells were washed twice with 1X PBS and observed by fluorescent microscope [21].

\section{Results and discussion}

Synthesis and characterization of novel $\left[\operatorname{Ru}(\text { bpy })_{2}(\text { bzpic })_{2}\right]^{2+}$ complex

The novel $\left[\mathrm{Ru}(\mathrm{bpy})_{2}(\text { bzpic })_{2}\right]^{2+}$ complex was synthesized by refluxing $\left[\mathrm{Ru}(\mathrm{bpy})_{2} \mathrm{Cl}_{2}\right]$ with bzpic ligand in the ratio 1:2 and the procedure for the synthesis is illustrated in Scheme 1. The synthesized $\left[\mathrm{Ru}(\mathrm{bpy})_{2}(\text { bzpic })_{2}\right]^{2+}$ cationic complex involves the coordination of $\mathrm{Ru}(\mathrm{II})$ atom with 2 bidentate bpy and 
2 mono dentate bzpic ligands via nitrogen atom of pyridine moiety, forming an octahedral complex. The complex is a dark red colored stable solid, soluble in water and organic solvents. The synthesized $\left[\mathrm{Ru}(\mathrm{bpy})_{2}(\mathrm{bzpic})_{2}\right]^{2+}$ complex was found to be thermally stable and soluble in water, acetonitrile, acetone, DMSO and DMF. The percentage of C, H, O and $\mathrm{N}$ was determined by elemental analysis. The elemental analysis report of the complex was in accordance with the theoretical value. Furthermore, the synthesized complex was characterized by UV, FTIR, ${ }^{1} \mathrm{H}$ NMR, ${ }^{13} \mathrm{C}$ NMR and mass spectral techniques.

a)

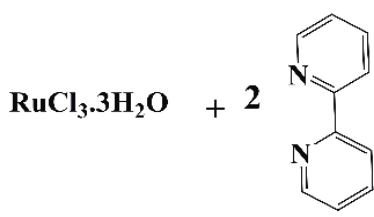

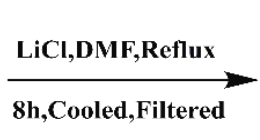

8h,Cooled,Filtered<smiles></smiles>

Cis-[Ru(bpy $\left.)_{2} \mathrm{Cl}_{2}\right]$

b)

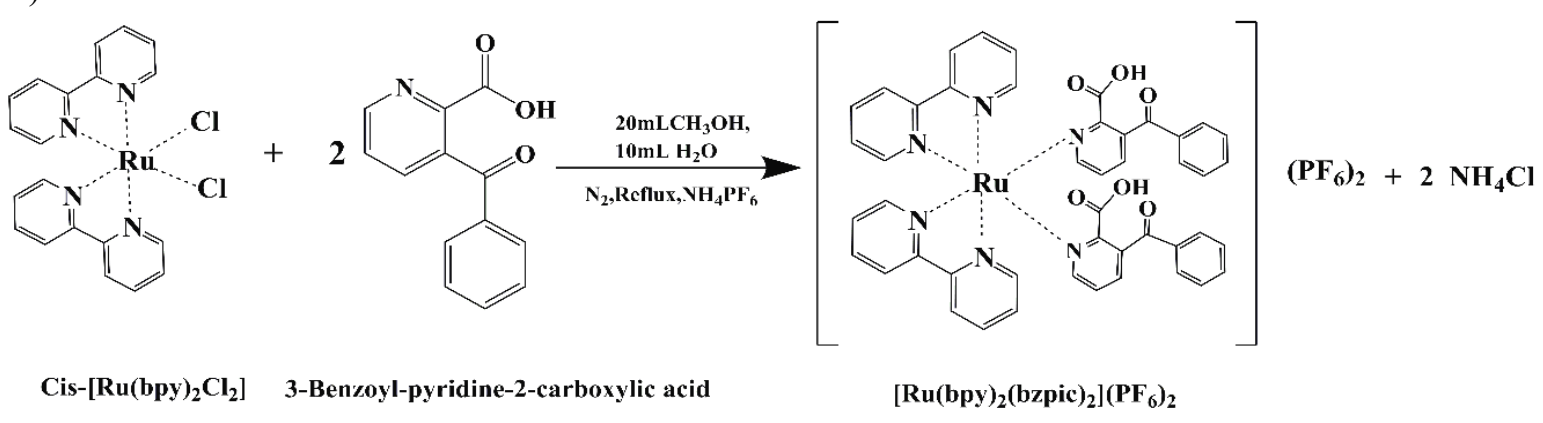

Scheme 1 a) Synthesis of $\left[\mathrm{Ru}(\mathrm{bpy})_{2} \mathrm{Cl}_{2}\right]$ and b) synthesis of $\left[\mathrm{Ru}(\mathrm{bpy})_{2}(\mathrm{bzpic})_{2}\right]\left(\mathrm{PF}_{6}\right)_{2}$ complex.

The absorption spectrum of $\left.\left[\mathrm{Ru}(\mathrm{bpy})_{2} \text { (bzpic }\right)_{2}\right]^{2+}$ complex in aqueous medium shows peaks at 246 , $291.5,340$ and $476.5 \mathrm{~nm}$, respectively (Figure 1). The peaks at 246 and $476.5 \mathrm{~nm}$ assigned to the $\mathrm{d} \pi-\pi^{*}$ metal to ligand charge transfer (MLCT) transition. The MLCT transition involves electronic excitation from the metal orbital $[\mathrm{d} \pi(\mathrm{Ru})]$ to the ligand centered acceptor $\pi^{*}$ orbitals. The peak at $291.5 \mathrm{~nm}$ corresponds to the ligand centered (LC) $\pi-\pi^{*}$ transition and the shoulder peak at $340 \mathrm{~nm}$ is due to metal centered transition. 


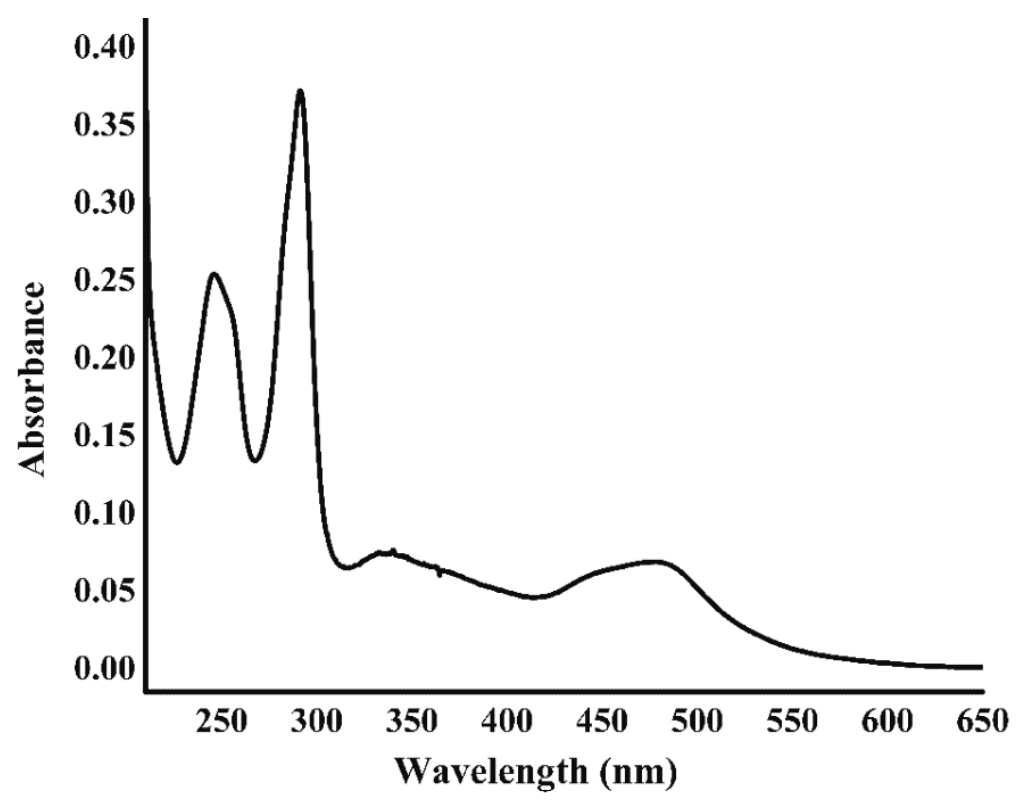

Figure 1 UV Spectrum of $\left[\mathrm{Ru}(\mathrm{bpy})_{2}[\text { bzpic })_{2}\right]\left(\mathrm{PF}_{6}\right)_{2}$ complex.

The FTIR spectrum of the $\left[\mathrm{Ru}(\mathrm{bpy})_{2}(\text { bzpic })_{2}\right]^{2+}$ complex (Figure 2) shows absorption bands at $3583,2920,2852$, 1788, 1764, 1653, 1662, 1681, 1585, 1558, 1473, 1411, 1286, 1321, 1336, 1344, 1379, 1321,947 and $844 \mathrm{~cm}^{-1}$. The peaks at 3583,1788 and $1411 \mathrm{~cm}^{-1}$ indicate the $-\mathrm{OH}$ stretching, $\mathrm{C}=\mathrm{O}$ stretching and $-\mathrm{OH}$ bending frequencies of carboxylic acid group of bzpic ligands. The peak at $1764 \mathrm{~cm}^{-1}$ indicates the $\mathrm{C}=\mathrm{O}$ stretching of the keto group present in the bzpic ligands. The peaks at 2920 and 2852 $\mathrm{cm}^{-1}$ are assigned for aromatic $\mathrm{C}-\mathrm{H}$ stretching. The bands at $1681,1662,1653,1585,1558$ and $1473 \mathrm{~cm}^{-1}$ described the $\mathrm{C}=\mathrm{C}$ stretching modes of the pyridine and benzene rings. These indicate the existence of the pyridine and aromatic rings group. The peaks found at 1379, 1344, 1336, 1321, 1286, 947 and $844 \mathrm{~cm}^{-1}$ are assigned for the $\mathrm{C}-\mathrm{N}$ and $\mathrm{C}-\mathrm{H}$ stretching and bending vibrations of pyridine and benzene moiety. Thus, the FTIR data confirms the formation of the $\left[\mathrm{Ru}(\mathrm{bpy})_{2}(\mathrm{bzpic})_{2}\right]^{2+}$ complex.

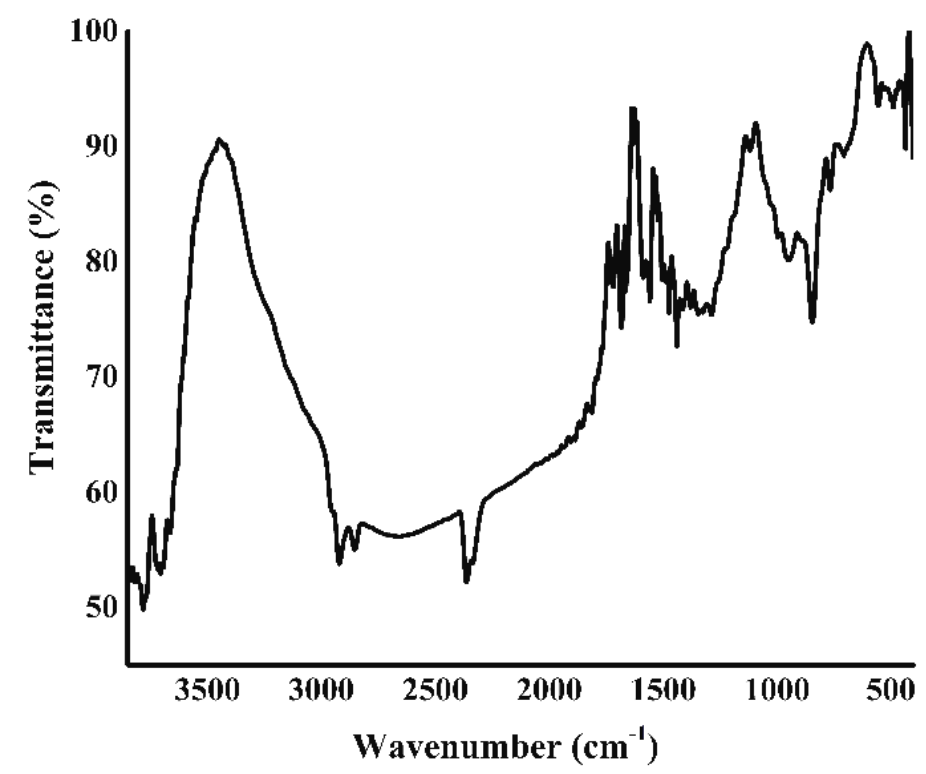

Figure 2 FTIR spectrum of the $\left[\mathrm{Ru}(\mathrm{bpy})_{2}(\text { bzpic })_{2}\right]^{2+}$ complex. 
The ${ }^{1} \mathrm{H}-\mathrm{NMR}$ spectrum of $\left[\mathrm{Ru}(\mathrm{bpy})_{2}(\mathrm{bzpic})_{2}\right]^{2+}$ complex at $400 \mathrm{MHz}$ was subsequently recorded in DMSO- $\mathrm{d}_{6}$. The ${ }^{1} \mathrm{H}-\mathrm{NMR}$ spectrum of the complex associated with the bpy and bzpic ligands gets coordinated with the pyridine nitrogen atoms of bpy and bzpic ligands to form an octahedral geometry (Figure 3).

The bpy units shows that the $\mathrm{H}$ atoms attached to different proton environments exhibit the chemical shift signals of $\mathrm{H}^{3}$ and $\mathrm{H}^{3^{\prime}}$ at $8.84 \delta$, ppm $(1 \mathrm{H}, \mathrm{d}) ; \mathrm{H}^{4}$ and $\mathrm{H}^{4^{\prime}}$ at $7.64 \delta$, ppm $(1 \mathrm{H}, \mathrm{t}) ; \mathrm{H}^{5}$ and $\mathrm{H}^{5^{\prime}}$ at $7.36 \delta$, ppm $(1 \mathrm{H}, \mathrm{t}) ; \mathrm{H}^{6}$ and $\mathrm{H}^{6^{\prime}}$ at $8.68 \delta$, ppm $(1 \mathrm{H}, \mathrm{d})$, respectively to the Ru metal core centre. This ${ }^{1} \mathrm{H}-$ NMR data of bpy ligand is in accordance with the previously reported data [22]. The ancillary ligand bzpic containing picolinic acid group exhibits pyridine ring proton signals of $\mathrm{H}^{4}$ at $8.23 \delta$, ppm $(1 \mathrm{H}$, d); $\mathrm{H}^{5}$ at $8.19 \delta, \mathrm{ppm}(2 \mathrm{H}, \mathrm{t})$ and $\mathrm{H}^{6}$ at $8.86 \delta$, ppm $(1 \mathrm{H}, \mathrm{d})$. The $-\mathrm{COOH}$ group in the ortho-position of the pyridine nitrogen of picolinic acid exhibit a signal due to O-H protons at $9.99 \mathrm{ppm}$. The benzoyl group substituted in the meta-position of the picolinic acid group shows that the signals clearly belongs to the aromatic benzene protons. The 5 protons of the aromatic ring have the same chemical shift values ranges between $7.6-7.9 \delta$, ppm. $\mathrm{H}^{2}$ and $\mathrm{H}^{6}$ hydrogen atoms of benzene group of bzpic at $7.89 \delta$, ppm $(1 \mathrm{H}$, dd); $\mathrm{H}^{3}$ and $\mathrm{H}^{5}$ signals at $7.61 \delta$, ppm $(2 \mathrm{H}, \mathrm{tt}) ; \mathrm{H}^{4}$ signal at $7.64 \delta$, ppm $(2 \mathrm{H}, \mathrm{t})$. On complexation with ruthenium metal, the characteristic signals of pyridine, aromatic and $\mathrm{O}-\mathrm{H}$ protons are de-shielded and lie in the range of $7.6-9.99 \mathrm{ppm}[23]$.

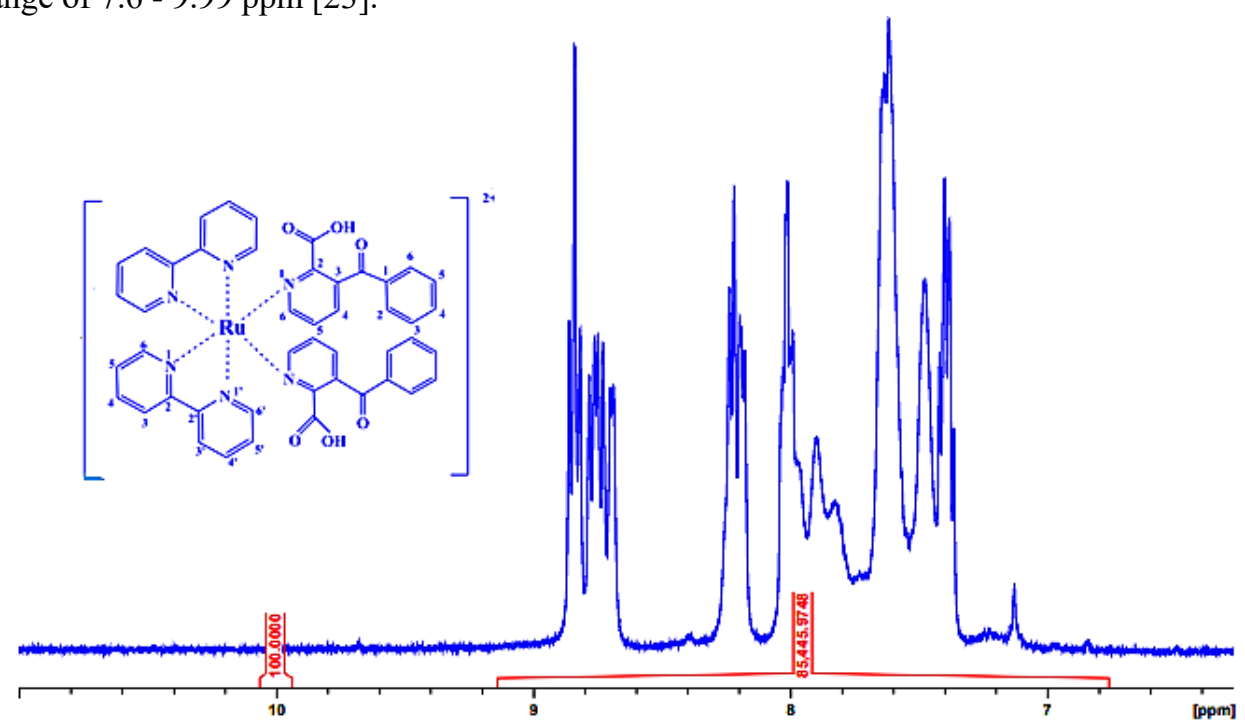

Figure $3{ }^{1} \mathrm{H}-\mathrm{NMR}$ spectrum of $\left[\mathrm{Ru}(\mathrm{bpy})_{2}(\text { bzpic })_{2}\right]^{2+}$ complex.

The ${ }^{13} \mathrm{C}$ NMR spectrum of the synthesized $\left[\mathrm{Ru}(\mathrm{bpy})_{2}(\text { bzpic })_{2}\right]^{2+}$ complex (Figure 4) shows a septet peak at the range of $39-41 \delta$, ppm which indicates the solvent DMSO peaks. A chemical shift at 151.61 $\delta$, ppm indicates the presence of $\mathrm{C}=\mathrm{O}$ group of carboxylic acid. 


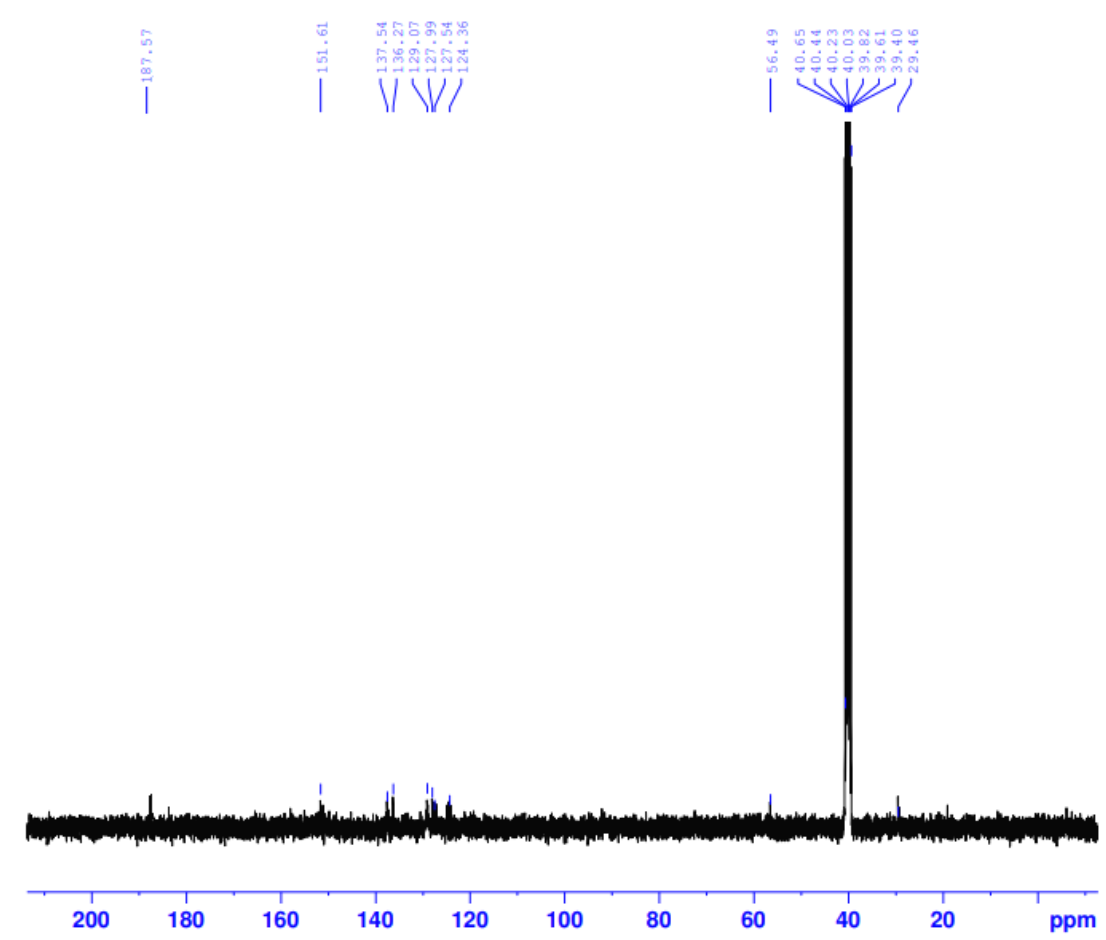

Figure $4{ }^{13} \mathrm{C}$ NMR spectrum of $\left[\mathrm{Ru}(\mathrm{bpy})_{2}(\mathrm{bzpic})_{2}\right]^{2+}$ complex.

The ${ }^{13} \mathrm{C}$-NMR signals of the aryl pyridine and benzene ring exhibit the same range between 124 $137 \mathrm{ppm}$. The carbon signals of benzene ring are predicted to be $\mathrm{C}_{1}$ at $137.54 \mathrm{ppm}, \mathrm{C}_{2,6}$ at $127.99 \mathrm{ppm}, \mathrm{C}_{4}$ at $129.06 \mathrm{ppm}, \mathrm{C}_{3,5}$ at $127.53 \mathrm{ppm}, \mathrm{C}_{5}$ at $124.35 \mathrm{ppm}$, respectively. The pyridine -2-carboxylic acid and the benzene ring are connected through a carbonyl keto group, the ${ }^{13} \mathrm{C}$ spectrum of $\mathrm{C}=\mathrm{O}$ group exhibit a carbon signal at a chemical shift as $187.57 \delta$, ppm, respectively. Hence, the obtained values confirm the formation of the $\left[\mathrm{Ru}(\mathrm{bpy})_{2}(\mathrm{bzpic})_{2}\right]^{2+}$ complex.

The experimental and theoretical values for the elemental analysis of $\left[\mathrm{Ru}(\mathrm{bpy})_{2}(\mathrm{bzpic})_{2}\right]^{2+}$ complex is in agreement with the proposed molecular formula $\mathrm{C}_{46} \mathrm{H}_{34} \mathrm{~F}_{12} \mathrm{~N}_{6} \mathrm{O}_{6} \mathrm{P} 2 \mathrm{Ru}$. The MALDI-TOF MS data of $\left[\mathrm{Ru}(\mathrm{bpy})_{2}(\mathrm{bzpic})_{2}\right]^{2+}$ complex (Figure 5) also supports for the proposed structure of the complex and is in good agreement with the assigned structure of the complex.

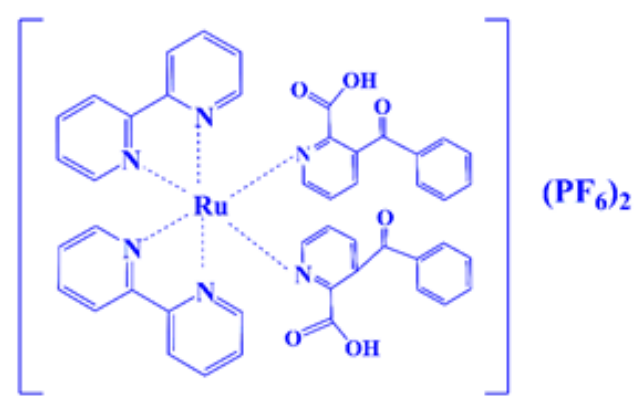

Figure 5 Structure of $\left[\mathrm{Ru}(\mathrm{bpy})_{2}(\mathrm{bzpic})_{2}\right]^{2+}$ complex.

The molecular ion peak with loss of $1 \mathrm{PF}_{6}^{-}$and $2 \mathrm{PF}_{6}{ }_{6}^{-}$counter ions show a peak value of 1012.345 , 867.994 corresponding to $\mathrm{M}^{+}-\mathrm{PF}_{6}{ }^{-}$and $\mathrm{M}^{+}-2 \mathrm{PF}_{6}^{-}$respectively. This obtained experimental value is in accordance with the calculated theoretical value. Thus, all the spectral data confirms the formation of $\left[\mathrm{Ru}(\mathrm{bpy})_{2}(\text { bzpic })_{2}\right]^{2+}$ complex. 


\section{Cytotoxic activity of novel $\left[\mathrm{Ru}(\mathrm{bpy})_{2}(\text { bzpic })_{2}\right]^{2+}$ complex}

The in vitro cytotoxic effect of novel $\left[\mathrm{Ru}(\mathrm{bpy})_{2}(\mathrm{bzpic})_{2}\right]^{2+}$ complex at various concentrations $(6.5$, $12.5,25,50,100 \mu \mathrm{g} / \mathrm{mL}$ ) against the control on L6 cell line is carried out by direct microscopic observation. The morphological changes of L6 cell line at various concentrations of $\left[\mathrm{Ru}(\mathrm{bpy})_{2}(\mathrm{bzpic})_{2}\right]^{2+}$ complex is compared against the control and is shown in the Figure 6.

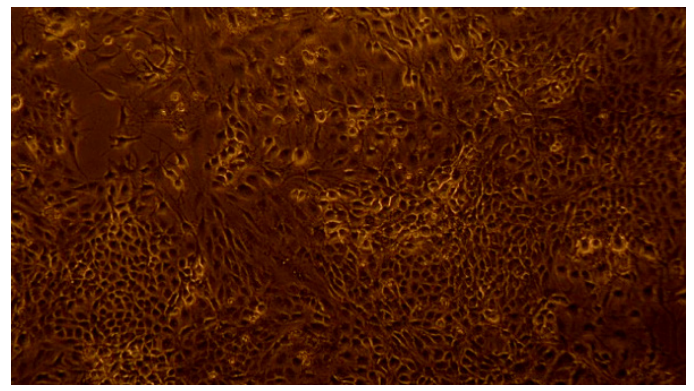

a) Control

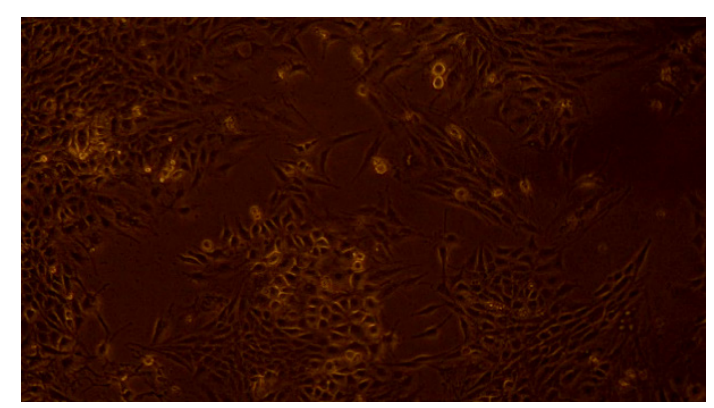

c) $12.5 \mu \mathrm{g} / \mathrm{mL}$

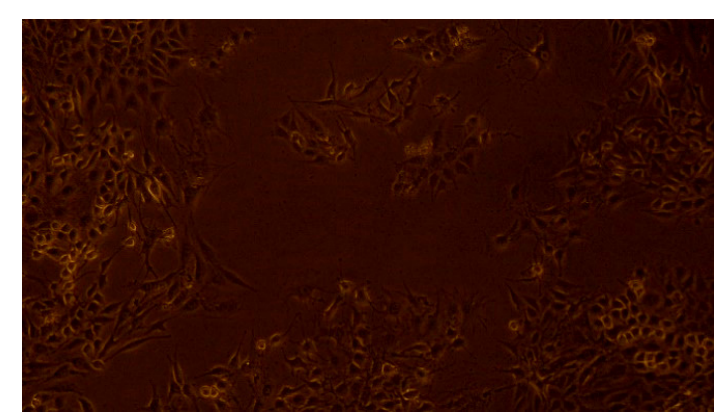

e) $50 \mu \mathrm{g} / \mathrm{mL}$

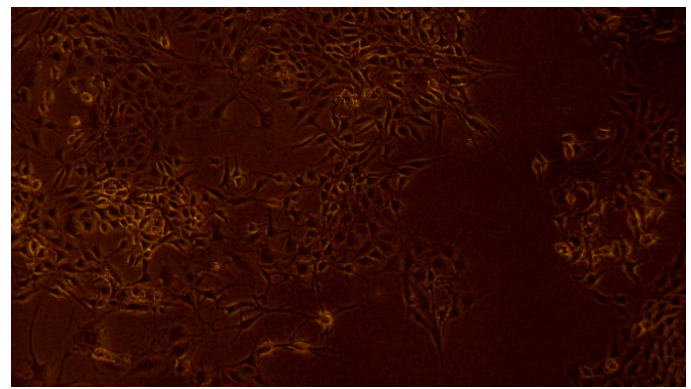

b) $6.25 \mu \mathrm{g} / \mathrm{mL}$

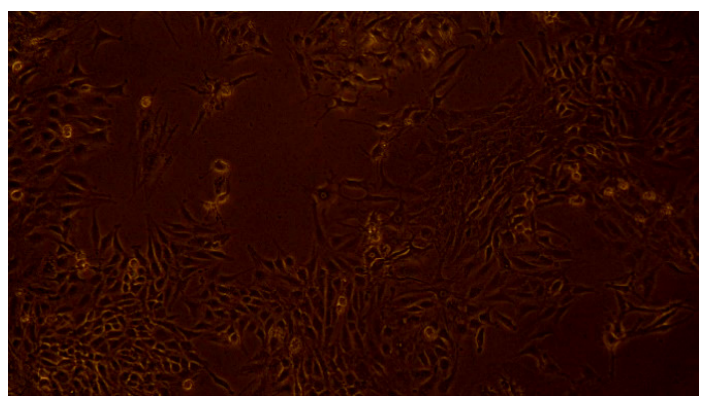

d) $25 \mu \mathrm{g} / \mathrm{mL}$

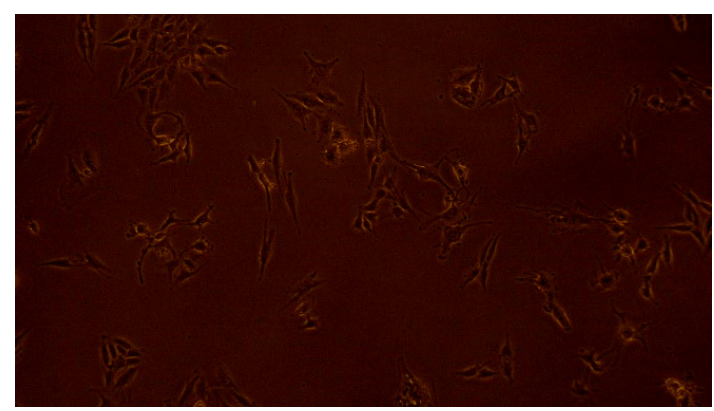

f) $100 \mu \mathrm{g} / \mathrm{mL}$

Figure 6 Morphological changes of $\left[\mathrm{Ru}(\mathrm{bpy})_{2}(\mathrm{bzpic})_{2}\right]^{2+}$ complex on normal L6 cell line at various concentrations.

The morphological changes on L6 cell line depict that as the concentration of the complex increases from 6.25 to $100 \mu \mathrm{g} / \mathrm{mL}$, the number of cells gets reduced because of shrinkage and minor cellular blebbing. The results show that the minimum inhibition of cells takes place at $50 \mu \mathrm{g} / \mathrm{mL}$ and the cells gets disrupted and shrinks towards the inner region of the normal L6 cells. At this concentration, the reduction in their shape and size takes place and no vacuolization is found, instead shrinkage and minor blebbing in the cells occurs. There is an enormous decrease in cells at $100 \mu \mathrm{g} / \mathrm{mL}$ which shows lower cellular viability and higher inhibition of the growth of cells. The present investigation revealed that the $\left[\mathrm{Ru}(\mathrm{bpy})_{2}(\text { bzpic })_{2}\right]^{2+}$ complex containing auxillary bipyridine ligands and the carbonyl group of benzoyl and picolinic acid enter the cellular components of the L6 cell line and damage the nucleus by reducing the cytoplasm present in the cells [24]. This direct in vitro cytotoxic evaluation of the synthesized 
$\left[\mathrm{Ru}(\mathrm{bpy})_{2}(\text { bzpic })_{2}\right]^{2+}$ complex clearly explains that the morphological changes in cells are purely based on concentrations through dose and time-dependent manner.

The percentage cellular viability of the complex on normal L6 cell line was calculated using MTT assay method. The cellular viability of the complex was measured by the mitochondrial dehydrogenase activity level using the yellow substrate MTT. The addition of MTT solution to the $\left[\mathrm{Ru}(\mathrm{bpy})_{2}(\mathrm{bzpic})_{2}\right]^{2+}$ complex makes the color changes from yellow to purple indicating that the cell death is taken place by the formation of formazan crystals. The formazan crystals are formed due to the reduction of MTT by the mitochondrial enzyme succinate dehydrogenase. The redox ability of living mitochondria converts the dissolved MTT into insoluble purple formazan [25]. The formazan crystals are subsequently solubilized using DMSO and the optical density is measured at $570 \mathrm{~nm}$. The intensity of the purple formazan crystal indicates the percentage cellular viability. The viable cells are quantified by the reaction of MTT with the sample on the cell line. The results revealed that as the concentration of the complex increases the percentage viability gets decreases (Table 1).

Table 1 Percentage cellular viability and percentage of growth inhibition of $\left[\mathrm{Ru}(\mathrm{bpy})_{2}(\text { bzpic })_{2}\right]^{2+}$ complex on SK-MEL-28 cell line and L6 cell line.

\begin{tabular}{ccccc}
\hline $\begin{array}{c}\text { Concentration } \\
(\boldsymbol{\mu g} / \mathbf{m L})\end{array}$ & $\begin{array}{c}\text { \% cellular viability on } \\
\text { SK-MEL-28 cell line }\end{array}$ & $\begin{array}{c}\text { \% of growth Inhibition } \\
\text { on SK-MEL-28 cell line }\end{array}$ & $\begin{array}{c}\text { \% cellular viability } \\
\text { on L6 cell line }\end{array}$ & $\begin{array}{c}\text { \% of growth Inhibition } \\
\text { on L6 cell line }\end{array}$ \\
\hline 0 & 100 & 0 & 100 & 0 \\
6.5 & 94.04 & 5.96 & 89.04 & 10.96 \\
12.5 & 83.33 & 16.67 & 86.3 & 13.7 \\
25 & 63.09 & 36.91 & 78.08 & 21.92 \\
50 & 40.47 & 59.53 & 52.05 & 47.95 \\
100 & 19.04 & 80.96 & 21.91 & 78.09 \\
$\mathbf{I C}_{\mathbf{5 0}}(\boldsymbol{\mu g} / \mathbf{m L})$ & $\mathbf{3 9 . 1 0 9}$ & & $\mathbf{5 5 . 3 1 5}$ & \\
\hline
\end{tabular}

The minimum inhibitory concentration, $\mathrm{IC}_{\mathbf{5 0}}$ value for $\mathrm{L} 6$ cell line is $55.315 \mu \mathrm{g} / \mathrm{mL}$ is found to be less than $100 \mu \mathrm{g} / \mathrm{mL}$. The $\mathrm{IC}_{\mathbf{5 0}}$ value indicates that the complex shows less cytotoxicity, the -COOH group could not easily penetrate the cellular membrane of normal cells and thus leads to lower cytotoxicity. This lower cytotoxicity is due to the carboxyl group of picolinic acid ligand present in the novel $\left[\mathrm{Ru}(\mathrm{bpy})_{2}(\text { bzpic })_{2}\right]^{2+}$ complex. Kamatchi et.al. [26] have reported the in vitro cytotoxic activity of 3 new ruthenium(II) complexes [ $\left.\mathrm{RuCl}_{2}(\mathrm{bpy})(\mathrm{S}-\mathrm{DMSO})_{2}\right]$, $\left[\mathrm{RuCl}_{2}\left(\mathrm{H}_{2} \mathrm{~L} 1\right)(\mathrm{S}-\mathrm{DMSO})_{2}\right]\left(\mathrm{H}_{2} \mathrm{~L}=2,2^{\prime}\right.$-bipyridine4,4' -dicarboxylic acid) and $\left[\mathrm{RuCl}_{2}\left(\mathrm{H}_{2} \mathrm{~L} 2\right)(\mathrm{S}-\mathrm{DMSO})_{2}\right]\left(\mathrm{H}_{2} \mathrm{~L} 2=2,2^{\prime}\right.$-bipyridine-5,5' -dicarboxylic acid $)$ on NIH 3 T3 and HEK 293 normal cells by MTT assay method. The carboxyl moiety presents in the $2^{\text {nd }}$ and $3^{\text {rd }}$ complexes may play a critical role. The cytotoxic activity against NIH 3T3 and HEK 293 normal cells and the $\mathrm{IC}_{50}$ values of these complexes are found to be above $1000 \mathrm{mM}$.

The cellular uptake and apoptosis effect of $\left[\mathrm{Ru}(\mathrm{bpy})_{2}(\text { bzpic })_{2}\right]^{2+}$ complex at $\mathrm{IC}_{50}$ value, 55.315 $\mu \mathrm{g} / \mathrm{mL}$ of L6 cell lines is studied by fluorescence microscopy using double staining method. In apoptosis study, AO dye emits green fluorescence by both viable and non-viable cells while EB emits red fluorescence by non-viable cells when gets intercalated into the DNA [27]. The [Ru(bpy $\left.)_{2}(\text { bzpic })_{2}\right]^{2+}$ complex on normal L6 cell line shows bright-green stained nucleus with chromatin condensation indicates early apoptotic effect and orange fluorescence indicates normal cells of L6 cell line (Figure 7). The early apoptotic inference on L6 cell line indicates that the synthesized $\left[\mathrm{Ru}(\mathrm{bpy})_{2}(\mathrm{bzpic})_{2}\right]^{2+}$ complex shows less cytotoxic effect. This is due to the damage in the DNA by nuclear chromatin condensation and by fragmenting the DNA. 


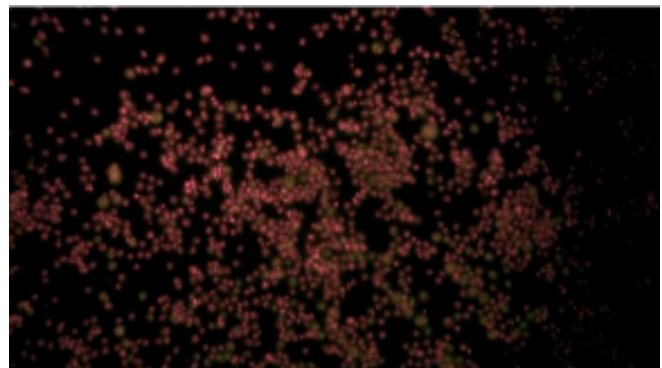

a) Control

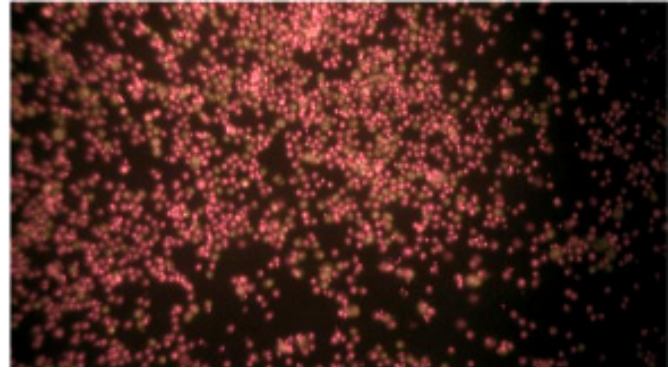

b) $55.315 \mu \mathrm{g} / \mathrm{mL}$

Figure 7 Fluorescent microscopic image of $\left[\mathrm{Ru}(\mathrm{bpy})_{2}(\text { bzpic })_{2}\right]^{2+}$ complex on L6 cell line.

\section{Anticancer ativity of novel $\left[\mathrm{Ru}(\mathrm{bpy})_{2}(\mathrm{bzpic})_{2}\right]^{2+}$ complex}

The evaluation of antiproliferative effect of $\left[\mathrm{Ru}(\mathrm{bpy})_{2}(\mathrm{bzpic})_{2}\right]^{2+}$ complex at various concentrations $(6.5,12.5,25,50$ and $100 \mu \mathrm{g} / \mathrm{mL})$ against the control on SK-MEL-28 cell line is carried out by direct microscopic observation. The cancerous SK-MEL-28 cell line when treated with $6.25 \mu \mathrm{g} / \mathrm{mL}$ of the complex shows cell shrinkage initially and gets elevated towards the centre of the cells and forms a cluster followed by cell blebbing at $12.5 \mu \mathrm{g} / \mathrm{mL}$. As the concentration increases from 25 to $50 \mu \mathrm{g} / \mathrm{mL}$, the number of cells gets decreased and forms vacuoles. There is an enormous decrease in cells at $100 \mu \mathrm{g} / \mathrm{mL}$, which shows lower cellular viability and higher inhibition of the growth of cells. Cellular morphological changes occurred on SK-MEL-28 cell line at different concentrations of the complex. It was monitored through the invitro antiproliferative microscopic evaluation. The morphological changes of SK-MEL-28 cell line against the control SK-MEL-28 cells are recorded using phase contrast microscope (Figure 8). The result showed that a higher magnification was done via autophagic vacuoles formation [24].

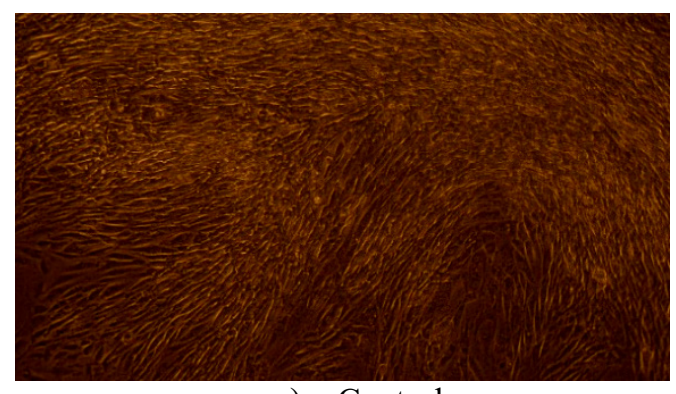

a) Control

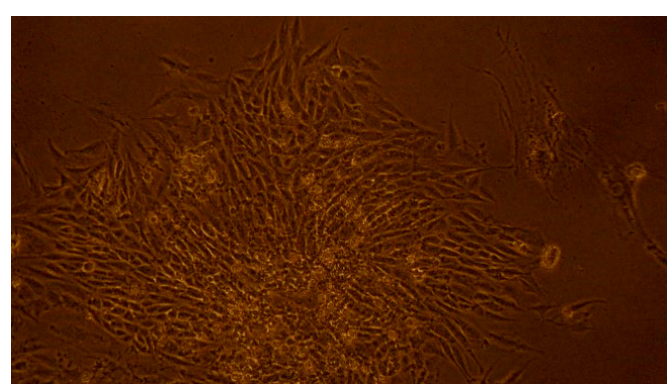

c) $12.5 \mu \mathrm{g} / \mathrm{mL}$

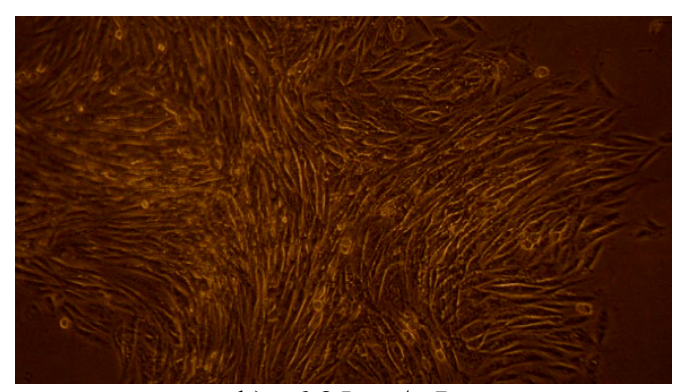

b) $6.25 \mu \mathrm{g} / \mathrm{mL}$

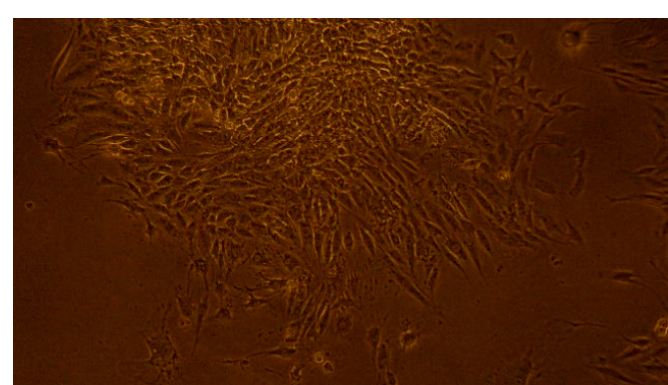

d) $25 \mu \mathrm{g} / \mathrm{mL}$ 


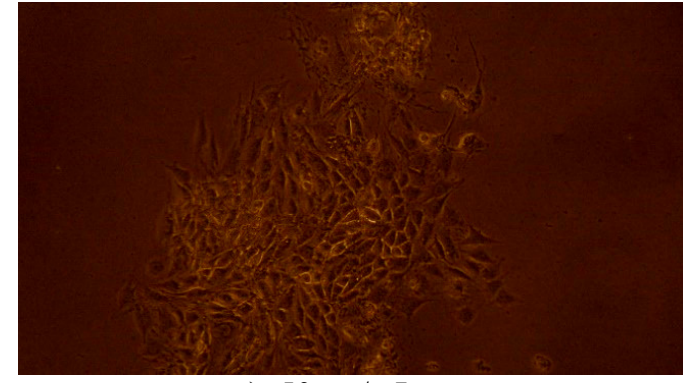

e) $50 \mu \mathrm{g} / \mathrm{mL}$

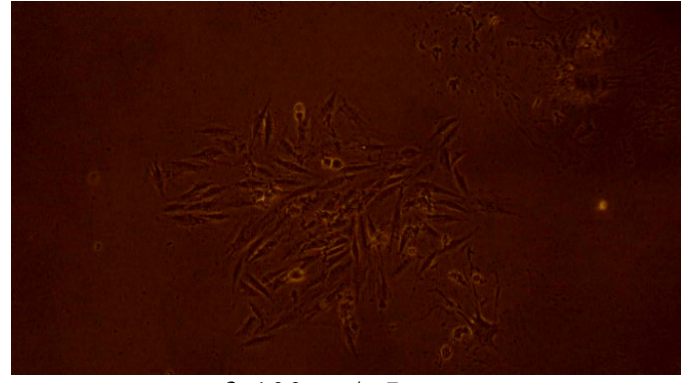

f) $100 \mu \mathrm{g} / \mathrm{mL}$

Figure 8 Morphological changes of $\left[\mathrm{Ru}(\mathrm{bpy})_{2}(\mathrm{bzpic})_{2}\right]^{2+}$ complex on cancerous SK-MEL-28 cell line at various concentrations.

The changes in the morphology of the cells are due to the production of reactive oxygen species (ROS). Cancer cells normally exist under oxidative stress characterized by the elevated levels of ROS when compared to non-turmorigenic cells [27]. Many chemotherapeutic agents are known to display their antitumor effect by inducing apoptosis through generation of high ROS levels [28]. The ROS production directly damage the cancer cells and leads to morphological disruption by the interaction of bzpic ligand present in the $\left[\mathrm{Ru}(\mathrm{bpy})_{2}(\text { bzpic })_{2}\right]^{2+}$ complex. The recorded images of SK-MEL-28 cells against the control at various concentrations of $\left[\mathrm{Ru}(\mathrm{bpy})_{2}(\text { bzpic })_{2}\right]^{2+}$ complex shows initial shrinkage, cluster cell formation due to chromatin condensation, leading to cellular vacuolization. Mitochondria plays a significant role in cellular metabolism and pays a way for the production of ROS Species. Hence, the synthesized complex targets the nucleus of the cancerous cells than the other subcellular regions. The non-nuclear targets such as the mitochondria mainly focus on cell surface and possess anticancer activity. Pierroz and co-workers reported that $\left[\mathrm{Ru}(\mathrm{dppz})_{2}(\mathrm{CppH})\right]^{2+}(\mathrm{CppH}=2-(2-p y r i d y l)$ pyrimidine-4-carboxylic acid $)$ complex possesses 2 positive charges which gets accumulated in the mitochondria and show anticancer efficacy in A2780 cancer cells more efficacious in cisplatin-resistant A2780/CP70 cells. This also was predicted less cytotoxic than cisplatin in healthy MRC-5 cells [29]. Similarly, Deng et al, reported that the [Ru (phtpy)(bpy)Cl] $\mathrm{ClO}_{4}$ complex have displayed a similar effect of reducing intracellular ROS levels in A375 human skin (melanoma) cancer cells [30].

The percentage cellular viability of $\left[\mathrm{Ru}(\mathrm{bpy})_{2}(\text { bzpic })_{2}\right]^{2+}$ complex on SK-MEL-28 cell line is tabulated in Table 1. The results revealed that as the concentration of the complex increases, the percentage viability of SK-MEL-28 cell line decreases. The $\mathrm{IC}_{\mathbf{5 0}}$ value of this complex against the SKMEL-28 cell line is found to be $39.109 \mu \mathrm{g} / \mathrm{mL}$ and it shows good anticancer activity. This anticancer activity of $\left[\mathrm{Ru}(\mathrm{bpy})_{2}(\text { bzpic })_{2}\right]^{2+}$ complex on SK-MEL-28 cell line is mainly due to the presence of carbonyl group present in the bzpic ligand [31]. This obtained result is in accordance with vuradi et.al, the anticancer activity of Ru(II)-polypyridyl complexes having (2-(4-(diethoxymethyl)-1 H-imidazo[4,5-f] (1,10-phenanthroline) ) intercalative ligand performed on HeLa cell line and the $\mathrm{IC}_{50}$ values for complexes are $39 \pm 4.6 \mathrm{mM}, 44.3 \pm 6.3$ and $49 \pm 8 \mathrm{mM}$, respectively [32]. The bpy ligands present in the $\left[\mathrm{Ru}(\text { bpy })_{2}(\text { bzpic })_{2}\right]^{2+}$ complex also plays an important role in the anticancer activity on SK-MEL-28 cell line. Zhang et.al. [33] reported that Ru(II)-polypyridyl complexes having ancillary bipyridine ligand plays a major role in the anticancer activity on SK-MEL-28 cell line.

The free - $\mathrm{COOH}$ group present in the pyridine ring of picolinic acid plays a major role in the in vitro antiproliferative activity. They get readily bind to surfaces of the rapidly growing cancer cells, which leads to minimum inhibitory concentration at $39.109 \mu \mathrm{g} / \mathrm{mL}$. Similar results are reported in accordance with the in vitro cytotoxic activity of the $\mathrm{Ru}(\mathrm{II})-2,2^{\prime}$-bipyridine-5,5' -dicarboxylic acid complexes against HCT-15, HeLa, SKOV3, MCF7 and SKMEL-2 human cancer cells using SRB assay [26]. The antiproliferative activity of the SK-MEL-28 cell line using MTT assay is compared against the reported SK-MEL-2 cell line using SRB assay method. It showed the $\mathrm{IC}_{50}$ value to be $235,279 \mu \mathrm{M}$, respectively. This is evident and clear that the presence of $\mathrm{COOH}$ group in the synthesized $\left[\mathrm{Ru}(\mathrm{bpy})_{2}(\text { bzpic })_{2}\right]^{2+}$ complex exhibit good antiproliferative activity [26].

The cellular uptake and apoptosis effect of $\left[\mathrm{Ru}(\mathrm{bpy})_{2}(\text { bzpic })_{2}\right]^{2+}$ complex on SK-MEL-28 cell line at $\mathrm{IC}_{50}$ value $39.109 \mu \mathrm{g} / \mathrm{mL}$ is studied by fluorescence microscopy using double staining method. The $\left[\mathrm{Ru}(\text { bpy })_{2}(\text { bzpic })_{2}\right]^{2+}$ complex on SK-MEL-28 cell line shows bright orange-stained nuclei with chromatin condensation indicating the inference of late apoptotic effect (Figure 9). 


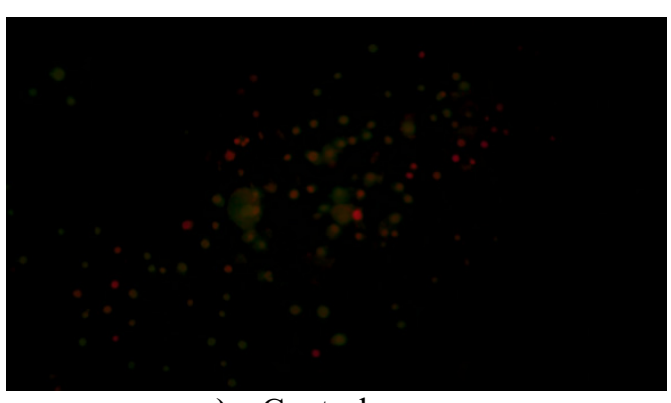

a) Control

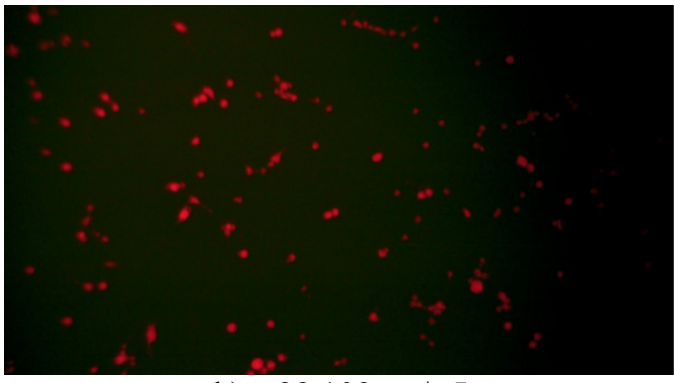

b) $39.109 \mu \mathrm{g} / \mathrm{mL}$

Figure 9 Fluorescent microscopic image of $\left[\mathrm{Ru}(\mathrm{bpy})_{2}(\text { bzpic })_{2}\right]^{2+}$ complex on SK-MEL-28 cell line.

The late apoptotic inference on SK-MEL-28 cell line indicates that the synthesized $\left[\mathrm{Ru}(\mathrm{bpy})_{2}(\mathrm{bzpic})_{2}\right]^{2+}$ complex shows good in vitro antiproliferative effect. This is due to the damage in the DNA either by chromatin condensation or by the fragmentation of the DNA. The bright-orange stained nucleus, which indicates apoptotic cells of SK-MEL-28 cell line and green fluorescence indicates normal cells of SK-MEL-28 cell line [28]. The fluorescent and the direct microscopic images of $\left[\mathrm{Ru}(\mathrm{bpy})_{2}(\mathrm{bzpic})_{2}\right]^{2+}$ complex on SK-MEL-28 cell line clearly indicates that the synthesized complex exhibit an intracellular site of localization within the cell lines. This result is in accordance with the reported studies that are conducted to monitor the intracellular localization and uptake of $\left[\mathrm{Ru}(\mathrm{bpy})_{2} \mathrm{O}-\right.$ $\mathrm{CPIP}] 2 \mathrm{PF}_{6},\left[\mathrm{Ru}(\mathrm{phen})_{2} \mathrm{o}-\mathrm{CPIP}\right] 2 \mathrm{PF}_{6}$ and $\left[\mathrm{Ru}(\mathrm{biq})_{2} \mathrm{o}-\mathrm{CPIP}\right] 2 \mathrm{PF}_{6}$ complexes with A549 cells by utilizing the photophysical properties of the complexes [34]. Similarly, observation is also obtained in the synthesized $\left[\mathrm{Ru}(\mathrm{bpy})_{2}(\text { bzpic })_{2}\right]^{2+}$ complex. The complex gets accumulated into the cell cytoplasm stained within the nucleus, the cellular uptake, accumulation in the cytoplasm, and nuclear stained by the complex, which indicate the apoptosis of cell death.

The $\left[\mathrm{Ru}(\text { bpy })_{2}(\text { bzpic })_{2}\right]^{2+}$ complex possess steric effect and aromatic $\pi-\pi$ stacking interactions between the bpy ligands and the co-ligands exhibit an apoptotic effect and thus inhibits the growth of cancer cells [35]. The synthesized $\left[\mathrm{Ru}(\mathrm{bpy})_{2}(\text { bzpic })_{2}\right]^{2+}$ complex shows good antiproliferative effect and less cytotoxicity on SK-MEL-28 and normal L6 cell lines. The growth inhibition in cancer cell line and less cytotoxic nature of the complex leads to mitochondria depletion. The complex containing pyridine moiety of the picolinic acid and the benzoyl group present in the complex induce apoptosis in carcinoma cells due to endoplasmic reticulum stress and reactive oxygen species production [36].

Hence, the synthesized $\left[\mathrm{Ru}(\mathrm{bpy})_{2}(\mathrm{bzpic})_{2}\right]^{2+}$ complex shows late apoptotic effect on SK-MEL-28 cell line and early apoptotic effect on L6 cell line. This complex also depicts that it shows excellent in vitro antiproliferative effect which inhibit the growth of cancerous cells and act as anti-skin cancer therapeutic agent with lower cytotoxicity. Thus, the metal complex containing bpy and bzpic ligands forms stable complex for the design of anticancer drugs. Hence the $\left[\mathrm{Ru}(\mathrm{bpy})_{2}(\mathrm{bzpic})_{2}\right]^{2+}$ complex may be administered as an effective anti-skin cancer drug to inhibit the growth of skin related sores and cancers.

\section{Conclusions}

The in vitro antiproliferative and cytotoxic activity of novel $\left[\mathrm{Ru}(\mathrm{bpy})_{2}(\text { bzpic })_{2}\right]^{2+}$ complex on SKMEL-28 and normal L6 cell lines was investigated. The morphological changes of SK-MEL-28 and normal L6 cell lines at various concentrations of the complex under direct microscopic observation exhibit cell shrinkage and minor blebbing leading to cell death. The percentage of the cellular viability of the $\left[\mathrm{Ru}(\mathrm{bpy})_{2}(\mathrm{bzpic}) 2\right]^{2+}$ complex on SK-MEL-28 and normal L6 cell lines revealed that the percentage of growth inhibition of the cell decreases with an increase in the concentration of the complex. The $\mathrm{IC}_{50}$ value of $\left[\mathrm{Ru}(\mathrm{bpy})_{2}(\text { bzpic })_{2}\right]^{2+}$ complex on SK-MEL-28 and normal L6 cell lines is found to be 39.109 and $55.315 \mu \mathrm{g} / \mathrm{mL}$. The fluorescent microscopic image depicts that the synthesized $\left[\mathrm{Ru}(\mathrm{bpy})_{2}(\mathrm{bzpic})_{2}\right]^{2+}$ complex shows early apoptotic effect on L6 cell line and late apoptotic effect on SK-MEL-28 cells. The complex containing the intercalating bzpic ligands induce apoptosis and inhibit the growth of cancerous SK-MEL-28 cells by binding on the surface of the cells. It fails to penetrate through the normal L6 cells, leading to lower cytotoxicity. Hence, it is evident and clear that the synthesized $\left[\mathrm{Ru}(\mathrm{bpy})_{2}(\mathrm{bzpic})_{2}\right]^{2+}$ complex shows good antiproliferative effect and less cytotoxicity on SK-MEL-28 and normal L6 cell lines. All the results clearly indicate that the $\left[\mathrm{Ru}(\mathrm{bpy})_{2}(\text { bzpic })_{2}\right]^{2+}$ complex has a remarkable capacity to inhibit the growth of SK-MEL cell through dose and time-dependent manner with less cytotoxicity. Thus, 
the synthesized complex shows good anti-skin cancer effect with less cytotoxicity towards living cells and can be suggested as an effective anti-skin cancer drug.

\section{References}

[1] P Das, N Deshmukh, N Badore, C Ghulaxe and P Patel. A review article on melanoma. J. Pharm. Sci. Res. 2016; 8, 112-7.

[2] E Perera, N Gnaneswaran, N Jennens and RR Sinclair. Malignant Melanoma. Health Care 2014; 2 , $1-19$.

[3] N Popgeorgiev, B Bonneau, J Prudent and G Gillet. Control of programmed cell death during zebrafish embryonic development. In: Y Bozkurt (Ed.). Recent advances in zebrafish researches. IntechOpen, 2018.

[4] G Fridman, A Shereshevsky, MM Jost, AD Brooks, A Fridman, AGV Vasilets and G Friedman. Floating Electrode dielectric barrier discharge plasma in air promoting apoptotic behavior in melanoma skin cancer cell lines. Plasma Chem. Plasma. Process. 2007; 27, 163-76.

[5] RG Kerry, KE Ukhurebor, S Kumari, GK Maurya, S Patra, B Panigrahi, S Majhi, JR Rout, MDP Rodriguez-Torres, G Das, HS Shin and JK Patra. A comprehensive review on the applications of nano-biosensor-based approaches for non-communicable and communicable disease detection. Biomater. Sci. 2021; 9, 3576-602.

[6] RB Onyancha, UO Aigbe, KE Ukhurebor and PW Muchiri. Facile synthesis and applications of carbon nanotubes in heavy-metal remediation and biomedicals fields: A comprehensive review. $J$. Mol. Struct. 2021; 1238, 130462.

[7] U Ndagi, N Mhlongo and ME Soliman. Metal complexes in cancer therapy-an update from drug design perspective. Drug Des. Dev. Ther. 2017; 11, 599-616.

[8] JCS Lopes, JL Damasceno, PF Oliveira, APM Guedes, DC Tavares, VM Deflon, NP Lopes, M Pivatto, AA Batista, PIS Maia and GV Poelhsitz. Ruthenium(II) complexes containing antiinflammatory drugs as ligands: Synthesis, characterization and in vitro cytotoxicity activities on cancer cell lines. J. Braz. Chem. Soc. 2015; 26, 1838-47.

[9] FE Poynton, SA Bright, S Blasco, DC Williams, JM Kelly and T Gunnlaugsson. The development of ruthenium(II) polypyridyl complexes and conjugates for in vitro cellular and in vivo applications. Chem. Soc. Rev. 2017; 46, 7706-56.

[10] A Srishailam, YP Kumar, PV Reddy, N Nambigari, U Vuruputuri, SS Singh and S Satyanarayana. Cellular uptake, cytotoxicity, apoptosis, DNA-binding, photocleavage and molecular docking studies of ruthenium(II) polypyridyl complexes. J. Photochem. Photobiol. B Biol. 2014; 132, 11123.

[11] C Ravi, RK Vuradi, S Avudoddi, PK Yata, VR Putta, G Srinivas, R Merugu and S Satyanarayana. Synthesis, spectral studies, DNA binding, photocleavage, antimicrobial and anticancer activities of isoindol Ru(II) polypyridyl complexes. Nucleos. Nucleot. Nucleic Acids 2019; 38, 788-806.

[12] I Kostova. Ruthenium complexes as anticancer agents. Curr. Med. Chem. 2006; 13, 1085-107.

[13] Z Incesu, K Bljnkl, G Akalin and NG Karaburun. The effects of some phenanthroline ruthenium(II) complexes on A549 cell proliferation. Turk. J. Pharm. Sci. 2013; 10, 193-204.

[14] L Xu, NJ Zhong, YY Xie, HL Huang, GB Jiang and YJ Liu. Synthesis, characterization, in vitro cytotoxicity, and apoptosis-inducing properties of ruthenium(II) complexes. PloS One 2014; 9 , e96082.

[15] RS Grant, SE Coggan and GA Smythe. The physiological action of picolinic acid in the human brain. Int. J. Tryptophan. Res. 2009; 2, 71-9.

[16] P Subramaniam and NT Selvi. Picolinic acid promoted oxidative decarboxylation of phenyl sulfinylacetic acid by Cr(VI). Bull. Chem. Soc. Ethiop. 2016; 30, 137.

[17] PJ Aggett, PK Fenwick and H Kirk. An in vitro study of the effect of picolinic acid on metal translocation across lipid bilayers. J. Nutr. 1989; 119, $1432-7$.

[18] P Sengupta, R Dinda, S Gosch and WS Sheldrick. Synthesis and characterization of some ruthenium(II) complexes of N-heterocyclic carboxylic acids X-ray structures of cis-[Ru(PPh3)2( $\left.\left(\mathrm{L}^{1}\right)_{2}\right] \cdot 2 \mathrm{CH}_{3} \mathrm{OH}$ and cis-[Ru(PPh$\left.)_{3} 2\left(\mathrm{~L}^{3} \mathrm{H}\right)_{2}\right]\left(\mathrm{L}^{1}=\right.$ pyridine-2-carboxylic acid and $\mathrm{L}^{3} \mathrm{H}_{2}=$ imidazole 4,5-dicarboxylic acid). Polyhedron 2010; 20, 3349-54.

[18] EM Shoukry, NG Hosny, MF Amin and EF Mohamed. Complex formation equilibria of ternary complexes of $\mathrm{Cu}(\mathrm{II})$ involving pyridine-2-carboxylic acid and various biologically relevant ligands. Int. J. Curr. Res. Chem. Pharm. Sci. 2016; 3, 32-43. 
[19] A Sieroslawska and A Rymuszka. Assessment of the cytotoxic impact of cyanotoxin beta-Nmethylamino-L-alanine on a fish immune cell line. Aquat. Toxicol. 2019; 212, 214-21.

[20] JH Zhang, J Yu, WX Li and CP Cheng. Evaluation of $\mathrm{Mn}^{2+}$ stimulated and $\mathrm{Zn}^{2+}$ inhibited apoptosis in rat corpus luteal cells by flow cytometry and fluorochromes staining. Chin. J. Physiol. 1998; 41, 121-6.

[21] S Castellano, C Sun and R Kostelnik. Analysis of the NMR spectrum of pyridine. J. Chem. Phys. 1967; 46, 327.

[22] E Corral, ACG Hotze, HD Dulk, A Leczkowska, A Rodger, MJ Hannon and J Reedijk, Ruthenium polypyridyl complexes and their modes of interaction with DNA: Is there a correlation between these interactions and the antitumor activity of the compounds? J. Biol. Inorg. Chem. 2009; 14, 43948.

[23] C Irace, G Misso, A Capuozzo, M Piccolo, C Riccardi, A Luchini, M Caraglia, L Paduano, D Montesarchio and R Santamaria. Antiproliferative effects of ruthenium-based nucleolipidic nanoaggregates in human models of breast cancer in vitro: Insights into their mode of action. Sci. Rep. 2017; 7, 45236.

[24] M Galletta, F Puntoriero, S Campagna, C Chiorboli, M Quesada, S Goeb and R Ziessel. Absorption spectra, photophysical properties, and redox behavior of ruthenium(II) polypyridine complexes containing accessory dipyrromethene-BF2 chromophores. J. Phys. Chem. A 2006; 110, 4348-58

[25] TS Kamatchi, N Chitrapriya, SLA Kumar, JY Jung, H Puschmann, FR Fronczeke and K Natarajan. The effect of incorporating carboxylic acid functionalities into 2,2'-bipyridine on the biological activity of the complexes formed: Synthesis, structure, DNA/protein interaction, antioxidant activity and cytotoxicity. RSC Adv. 2017; 7, 16428-43

[26] J Wang and J Yi. Cancer cell killing via ROS: To increase or decrease, that is the question. Canc. Bio Ther. 2008; 7, 1875-84.

[27] MQ Warraicha, A Ghionb, L Perdisatta, LO Neilla, A Caseya and CO Connor. In vitro cytotoxicity, cellular uptake, reactive oxygen species and cell cycle arrest studies of novel ruthenium(II) polypyridyl complexes towards A549 lung cancer cell line. Drug Chem. Toxicol. 2019; 44, 319-29.

[28] V Pierroz, T Joshi, A Leonidova, C Mari, J Schur, I Ott, L Spiccia, S Ferrari and G Gasser. Molecular and cellular characterization of the biological effects of ruthenium(II) complexes incorporating 2-pyridyl-2-pyrimidine-4- carboxylic acid. J. Am. Chem. Soc. 2012; 134, 20376-87.

[29] Z Deng, P Gao, L Yu, B Ma, Y You, L Chan, C Mei and T Chen. Ruthenium complexes with phenylterpyridine derivatives target cell membrane and trigger death receptors-mediated apoptosis in cancer cells. Biomaterials 2017; 129, 111-26.

[30] JP Barolli, RS Corrêa, FS Miranda, JU Ribeiro, J Ellena, V Moreno, MR Cominettig and AA Batista. Polypyridyl ruthenium complexes: Novel DNA-Intercalating agents against human breast tumor. J. Braz. Chem. Soc. 2017; 28, 1879-89.

[31] RK Vuradi, K Dandu, PK Yata, RR Mallepally, N Chintakuntla, R Ch, SS Thakur, CM Rao, S Satyanarayana. Studies on the DNA binding and anticancer activity of Ru(ii) polypyridyl complexes by using a (2-(4-(diethoxymethyl)-1H-imidazo[4,5-f] [1,10] phenanthroline)) intercalative ligand. New J. Chem. 2018; 42, 846-59.

[32] C Zhang, BJ Han, CC Zeng, SH Lai, W Li, B Tang, D Wan, GB Jiang and YJ Liu. Synthesis, characterization, in vitro cytotoxicity and anticancer effects of ruthenium(II) complexes on BEL7402 cells. J. Inorg. Biochem. 2016; 157, 62-72.

[33] P Xiao, B Zheng, J Sun and J Yang. Biochanin A induces anticancer effects in SK-Mel-28 human malignant melanoma cells via induction of apoptosis, inhibition of cell invasion and modulation of NF-кB and MAPK signaling pathways. Oncol. Lett. 2017; 14, 5989-93.

[34] A Mori, T Suzukia, K Nakajima. Crystal structure of bis (2,2'-bipyridine) [N'-(quinolin-2ylmethylidene) pyridine-2-carbohydrazide]-ruthenium(II)bis (tetra fluoride borate) dichloromethane trisolvate. Acta Crystallogr. E Crystallogr. Comm. 2015; 71, 142-5.

[35] RZ Zarić, MS Pirković and N Hamzagić. Ruthenium(II) complexes as potential apoptosis inducers in cancer therapy. Serbian J. Exp. Clin. Res. 2019. https://doi.org/10.2478/sjecr-2019-0016. 